\title{
MULTICULTURALISM IN A TRANSNATIONAL REGIONAL COMMUNITY: EU SUBSIDIES AND CULTURAL HERITAGE IN SOUTHEAST POLAND
}

ABSTRACT The Bieszczady region of southeast Poland contains many traces of former multiethnic communities, and the transnational forces that destroyed them. With increasing frequency, the European Union logo marks EU involvement in cultural heritage projects throughout the region. In this article, I explore the interconnections among ethnicity, culture, and politics revealed in the ways Bieszczady residents make use of EU subsidies designated for the promotion of regional cultures. I argue that local agents cater to a vision of multiculturalism that bolsters EU values of cross-border cooperation and tolerance for diversity, but they do so in pursuit of regional goals. Ethnographic examples show they want to increase regional pride and promote development of the regional tourist sector so that residents will feel less compelled to emigrate in search of employment. Although "transnational regional community" sounds like an oxymoron, it is an apt characterization of the Bieszczady region (and by extension other borderlands of the $\mathrm{EU}$ ) because the transnational institution of the European Union provides the context in which particular kinds of regional identities become salient, albeit in multiple and fragmented ways.

Keywords: multiculturalism, European integration, heritage, Poland, EU subsidies 
Y ou cannot go very far in the Bieszczady region of southeast Poland without coming across traces of formerly thriving multiethnic communities, and the transnational forces that destroyed them. Some are as dramatic as the synagogue in Lesko, its size a reminder that before the Holocaust the town's Jewish population was larger than the Catholic one. Others are only visible to those who know what to look for, like fruit trees and foundation stones marking villages destroyed and abandoned during World War II. Efforts to preserve what remains have been undertaken by state agencies, local governments, and nongovernmental organizations. With increasing frequency, the European Union logo marks EU involvement in cultural heritage and cultural revitalization projects throughout Bieszczady. In this article, I explore the interconnections among ethnicity, culture, and politics revealed in the ways residents make use of EU subsidies designated for the promotion of regional cultures. I argue that while local agents cater to a vision of multiculturalism that bolsters EU values of cross-border cooperation and tolerance for diversity, they do so in pursuit of regional goals. Specifically, they want to increase local pride in Bieszczady and promote development of the local tourist sector so that residents will have reasons to stay rather than emigrate in search of employment. Ethnographic examples highlight the agency of local stakeholders within the constraints of EU funding priorities and values. They also expose the unintended consequences of ethnocultural politics within the EU, including the silencing of some regional histories in favor of others, the bolstering of bounded national categories, and the deepening of divisions between member and nonmember states. Although "transnational regional community" sounds like an oxymoron, it is an apt characterization of the Bieszczady region (and by extension other borderlands of the EU) because the transnational institution of the European Union provides the context in which particular kinds of multiethnic regional identities become salient.

At issue in what I am calling a transnational regional community is the multilayered convergence of seemingly opposing scales of identity and identification, at the more immediate regional level of "Bieszczady" and at the broader level of "Europe". Recent scholarship in anthropology about local-global interactions provides a useful base upon which to understand the conflations between various scales. While globalization is often narrowly defined in terms of economic processes associated with neoliberal reforms, and is assumed to involve the inexorable integration of smaller scales into a single, monolithic world system, anthropologists have emphasized instead the importance of cultural flows - of people, ideas, and meanings - and tend to show how processes of influence are multidirectional and fragmented. ${ }^{1}$ Anna Tsing ${ }^{2}$ compels us to be sensitive to the unevenness of globalizing processes, and the inequalities of power and wealth

A. Appadurai, 'Global Ethnoscapes: Notes and Queries for a Transnational Anthropology' in J.X. Inda, R. Rosaldo (eds.), The Anthropology of Globalization. A Reader, Malden (Mass.) 2008, pp. 47-63 (Blackwell Readers in Anthropology, 1); A. Tsing, 'The Global Situation', Cultural Anthropology, Vol. 15, No. 3 (2000), pp. 327-60, at <http://dx.doi.org/10.1525/can.2000.15.3.327>.

2 A. Tsing, 'The Global..., pp. 336-337, 342-347. 
that can be exacerbated by globalization. ${ }^{3}$ Contrary to common assumptions that global processes shape local places, she urges us to consider global and local processes that act upon local and global places. ${ }^{4}$ Even economic exchanges, involving flows of goods and capital, can mean different things in different places. Some compelling examples include the way iconic brands like McDonald's ${ }^{5}$ and Coca Cola ${ }^{6}$ are appropriated and transformed in specific cultural contexts. Anthropology's sensitivity to culture almost always leads back to such particularisms. In cases examined here, the multicultural values expressed in EU funding practices activate particular ways of thinking about and acting upon ethnic relationships, landscapes, and histories in the Bieszczady region of Poland, but they also provide a view into the ways in which macro and micro-level processes and places can be mutually constitutive.

Globalization theory is relevant to European integration because the European Union is the engine of broader global processes including the breakdown of barriers between member states, and the permeability of those borders to flows of capital, people and ideas; and yet, as Tsing and Appadurai remind us, these processes can be multiple, overlapping, and contradictory, ${ }^{7}$ and full of ironies, resistances, and disjunctures. ${ }^{8}$ Tsing and Appadurai's critiques also point to the limits of a more uniform world systems theory that divides the world into core, semiperiphery, and periphery. ${ }^{9}$ A world systems approach would position Bieszczady in the periphery of the urban Polish core, and at the easternmost boundary of the European Union. Additionally, it would emphasize how the mountain region is far from centers of power and decision-making, with limited sources of local capital. In this article, I focus instead on the ways in which the discourse and practices of local social entrepreneurs and civil servants harness some of the resources provided by the EU (and the Polish state) to advance local interests. They do so in ways that sometimes reproduce a world systems narrative, and other times lay claim to a different measure of value for Bieszczady, one in which, through a kind of symbolic inversion, the remoteness and lack of development that marks the region's peripherality also constitutes the region's distinctiveness.

Such claims of specialness are, in part, encouraged by EU rhetoric about regions, showing again that the micro and macro-levels are mutually constitutive. That is to say,

See also A. Chua, World on Fire. How Exporting Free Market Democracy Breeds Ethnic Hatred and Global Instability, New York 2004. Chua focuses in particular on the negative effects of global processes on the developing world, especially in places where power and wealth are concentrated within an ethnic minority that becomes a target for attacks by the impoverished majority.

A. Tsing, 'The Global..., p. 352.

5 M.Caldwell, 'Domesticating the French Fry: McDonald's and Consumerism in Moscow',Journalof Consumer Culture, Vol. 4, No. 1 (2004), pp. 5-26, at <http://dx.doi.org/10.1177/1469540504040902>; J. Watson (ed.), Golden Arches East. McDonald's in East Asia, Stanford 1997.

6 R. Foster, Coca-globalization. Following Soft Drinks from New York to New Guinea, New York 2008.

A. Tsing, 'The Global..., pp. 331-336.

$8 \quad$ A. Appadurai, 'Global Ethnoscapes..., pp. 49, 54.

9 I. Wallerstein, The Capitalist World-Economy. Essays, Vol. 2, Cambridge 1979, pp. 1-49 (Studies in Modern Capitalism). 
EU cultural policy puts forward a model that opposes a simple core-periphery model by claiming, on the one hand, common European values and traditions, and on the other, celebrating regional diversity within and between member states. "Unity in diversity" and "Europe of nations" discourses assert that the whole is only as great as the sum of its parts. Ethnic minorities and regional cultures are acknowledged as having inherent worth, on par with the cultures at the center of political and economic power. These claims resonate with social actors in Bieszczady, who express deep pride in their place of residence, and see its wildness as part of what makes it worthy of attention (via tourism and other kinds of investment) by the broader European community.

Meinhof and Tirandafyllidou explain, As a political ideal, multiculturalism means equal opportunity accompanied by cultural diversity in an atmosphere of mutual tolerance. ${ }^{10}$ In other words, associated multicultural policy aims to both recognize cultural diversity and take measures to insure social and economic equality. Kiwan and Meinhof further analyze the discourse of EU cultural policy to show a shift from "multiculturalism", in which cultures tend to be conceived as bounded ethnic units that should nevertheless be able to get along, to "diversity", which tends to advance a more progressive, anti-discrimination agenda encompassing other distinctions like sexual orientation and disability, as well as ethnicity. Diversity often separates groups into distinct categories in much the same way as multiculturalism, but also signals more fluid boundaries between categories. ${ }^{11}$ It remains to be seen how much this broader, a more flexible view of diversity, will be engaged in Poland, where more rigid notions of bounded ethnicities, some constituting autonomous nations and others ethnic minorities, predominate.

From the earliest deliberations about forming a union of European countries, organizers have questioned the extent to which separate nations would be willing to cede sovereignty to a supranational organization. The desire to prevent another world war was a strong motivating value, but the earliest agreements in the 1950s were limited to the economic realm. Uniting to advance mutually beneficial economic interests was more readily accepted, and was seen by many as a way to simultaneously strengthen independent sovereign states. Over time, collective involvement has extended to the political sphere, and also increasingly the cultural sphere. Despite the fact that the European Parliament has become a reality, divisions remain strong, as illustrated by the failure to pass the European Constitution in 2005. Additionally, heated cultural debates continue about a wide range of social policies, including access to abortion, equal rights for homosexuals, immigration, and the place of Christianity in European culture. At the heart of these debates remain questions about the degree to which member states will retain control over their own territory and people, whether a unified European culture exists, and the extent to which finding such common ground is possible and desirable.

These are big questions that deserve attention from a variety of disciplinary and

10 U.H. Meinhof, A. Triandafyllidou, 'Transcultural Europe: An Introduction to Cultural Policy in a Changing Europe' in eaedem (eds.), Transcultural Europe. Cultural Policy in a Changing Europe, New York 2006, p. 8.

11 N. Kiwan, U.H. Meinhof, 'Perspectives on Cultural Diversity: A Discourse-Analytical Approach' in U.H. Meinhof, A. Triandafyllidou (eds.), Transcultural Europe..., pp. 57-81. 
methodological perspectives. In my research project, I make use of the anthropological toolkit - participant-observation of heritage projects, ethnographic interviews with social entrepreneurs and civil servants, and textual analysis of project applications and reports. Close attention to everyday "micro-level" discourse and practices helps reveal how ordinary citizens receive, interpret, and deploy institutional "macro-level" ideology and resources. I focus on a particular place - the Bieszczady region of southeast Poland - and a particular group - residents engaged in regional development projects. I consider what negotiations at the local level reveal about global processes mediated by EU practices and policies.

\section{MULTICULTURALISM IN BIESZCZADY}

In Poland, multiethnic policies contend with the very strong hold the category of nation has on the social imagination. Even during the state socialist period, the internationalist ideology of communism, which played down national categories in favor of class-based unity, failed to displace national loyalties. On the contrary, the state sought to gain legitimacy by appropriating Polish symbols, ${ }^{12}$ and engaging in sometimes brutal processes of Polonization in ethnically mixed regions like Bieszczady. ${ }^{13}$ It remains to be seen whether the multiculturalism promoted by the European Union will be similarly molded to national interests. My conversations with Bieszczady social entrepreneurs and civil servants suggest that this may indeed be the case, but EU integration has also created a space that simultaneously empowers local sentiments of attachment and connections to the broader European sphere.

It is important to remember that ethnic diversity in Bieszczady is not something new; on the contrary, Poles, Ruthenians, and Jews populated the region for centuries. Elite landowners tended to be Poles, while villagers tended to display cultural traits associated with a cluster of small ethnic groups called Ruthenians (present day Ukrainians). ${ }^{14}$ Jews were mostly merchants and tradesmen living in towns and cities. Although they lived in the same communities, the boundaries between ethnic categories were sharply drawn. This sense of otherness characterized multicultural relations throughout Europe, and contributed to the ruthless realization of the logic of homogeneous nation-states - first by the murder of the Jews by the Nazis, and then by the forced resettlement of populations so that national communities better conformed to

12 J. Kubik, The Power of Symbols against the Symbols of Power. The Rise of Solidarity and the Fall of State Socialism in Poland, University Park 1994.

13 J. Buzalka, Nation and Religion. The Politics of Commemoration in South-East Poland, Berlin 2007 (Halle Studies in the Anthropology of Eurasia, 14); R. Lehman, 'Social(ist) Engineering: Taming the Devils of the Polish Bieszczady', Communist and Post-Communist Studies, Vol. 42, No. 3 (2009), pp. 423-444, at <http://dx.doi.org/10.1016/j.postcomstud.2009.07.004>; G. Thum, Uprooted. How Breslau Became Wroctaw during the Century of Expulsions, Princeton 2011.

14 See J. Falkowski, B. Pasznycki, Na pograniczu temkowsko-bojkowskim. Zarys etnograficzny, Lwów 1935; A. Fastnacht, Dzieje Leska do 1771 roku, Rzeszów 1988. 
postwar political boundaries. These processes led to the depopulation of Bieszczady, and the region gained a reputation as "wild" (dzikie) and "empty" (puste). The postwar socialist state viewed the region as a kind of blank slate, and sought to remake it in keeping with what Rosa Lehman calls the "high modernist socialist order" which the state wanted to realize throughout Poland. ${ }^{15}$ In contrast to the socialist vision which favored modernization of agriculture and industrial development, the mountains also gained a reputation for attracting "restless souls" (niespokojne duchy) - artists; criminals; and others - escaping the company of people and seeking adventure in Poland's "wild east". Both of these portraits produced silences; ${ }^{16}$ they said nothing about the prewar multiethnic communities that were wiped out by the Holocaust and mass resettlement.

The contemporary vision for the area, and the associated contradictions, correspond with various $\mathrm{EU}$ fund priorities, including economic development, environmentalism, and multiculturalism, each of which follows its own logic and values. In and around Bieszczady National Park, "wilderness" tourism is encouraged while simultaneously, in these same places, traces of abandoned villages are recovered and preserved for heritage tourists. Farmers receive subsidies for organic production, but have little recourse when their livestock is attacked by wolves with protected status. Logging for the local wood processing industry scars the view along hiking trails.

Similarly, the use of EU regional development funds such as ERDF, INTERREG, PHARE, and EQUAL is punctuated by disjunctures. These funds variously promote multiculturalism by espousing values like cross-border cooperation, tolerance for diversity within an increasingly cohesive Europe, and celebration of the cultural distinctiveness of ethnic minorities. They also advance broader EU goals to "balance levels of economic development", which in turn is seen as an important component of "cohesion" within Europe. The objective of the ERDF (European Regional Development Fund) is to encourage economic and social cohesion by reducing regional inequalities in development and promoting cross-border cooperation. ${ }^{17}$ INTERREG espouses the goal of encouraging cooperation across national and regional borders, both within the EU and between EU member and nonmember states. PHARE first provided funds to Poland and Hungary in 1989 to help reform their economic system, already with the idea of eventual EU integration; over the years, the program expanded to include development projects in other candidate countries in Eastern and Central Europe. ${ }^{18}$ The EQUAL initiative, co-financed by the EU and EU member states during the 2000-2006 period,

15 R. Lehman, 'Social(ist) Engineering..., p. 425.

16 For a discussion of silences and absences in collective memories, see I. Irwin-Zarecka, Frames of Remembrance. The Dynamics of Collective Memory, New Brunswick 1994.

17 For a brief description of the program and a link to the legislation, see European Regional Development Fund (ERDF) (2007-2012), Summaries of EU Legislation, at < http://europa.eu/legislation_summaries/agriculture/general_framework/g24234_en.htm>.

18 The name PHARE was originally an acronym for Poland and Hungary: Assistance for Reconstructing of their Economies. When its mission expanded to other countries, it became known simply as Phare. For a brief description of the program, see W. Bokajło, K. Dziubka (eds.), Unia Europejska. Leksykon integracji, Wrocław 2003, pp. 211-214. 
supported innovative, transnational projects aimed at tackling discrimination and disadvantage in the labour market. ${ }^{19}$ Local stakeholders often engage these values as a means to advance regional interests such as economic opportunity and celebration of regional worth. The interests at regional, national, and European scales can be complementary, but they are not necessarily so.

\section{CROSS-BORDER COOPERATION}

Some initiatives in Bieszczady champion cross-border cooperation in the form of tourism between neighboring countries. "Zielony Rower" (Green Bicycle, an affiliate of the international organization Greenways), creates and publicizes bicycle routes that extend from Poland into neighboring countries. The director of the NGO who helped realize this project emphasizes its success at bringing Slovak bicycle tourists into the region; he says he hopes being part of a wider network of bike routes will attract bicycle enthusiasts from farther afield, as well. Another successfully funded project is a zoo at a retreat center run by the Catholic charity organization Caritas. The priest who manages the center explained that Slovak, and occasionally Ukrainian, school groups visit the zoo. Although signs at the site advertise that PHARE funds for cross-border cooperation made the project possible, the priest did not express any strong feelings about the European Union or Poland's membership in the EU. Rather, he said he made use of EU funds because they provided him with a means of expanding and improving the facilities, and making them more attractive to tourists. His focus is on the local sphere.

A third example also illustrates how local social entrepreneurs make claims about encouraging cross-border cooperation less out of a commitment to multiculturalism than a desire for economic resources for tourism development. Józef, a civil servant, admits that he sometimes uses the promise of promoting relations across national borders to increase his chances of obtaining EU subsidies. He began a cooperative relationship with a district in Slovakia when someone from their agency asked his office to sign on as the foreign partner on one of their proposals. Since then, the two districts have cosigned a number of each other's projects. For example, Józef said, We applied for funds to build a tennis court and parking lot, and... this is funny... the application required evidence of trans-border investment - that two countries could benefit from it - so we had that district in Slovakia sign the application, also. In the application, submitted to INTERREG, Józef identified the goal to increase active tourism from Poland and neighboring countries and all of Europe as a means of promoting economic growth. Further, the project stated there would be at least five cultural events organized with the Slovak partner organization. Calling tourism "the best chance" for the transborder region, the proposal promised, Very often friendly connections form through this [kind of activity]. The application

19 See Welcome to EQEAL, European Commision, at <http://ec.europa.eu/employment_social/equal_ consolidated/index.html>. 
thus shows how a local leader tailored regional interests to the goals and priorities identified by EU funding instruments.

European integration can also deepen disjunctures and inequalities, thus illustrating the unevenness of global processes. Increased permeability of some political borders has contributed to the rigidity of others. In contrast to strengthening ties between EU member states, cross-border collaboration with Ukraine has become more difficult as a consequence of standards regulating non EU citizens' movement into the European Union. ${ }^{20}$ It has become harder and more costly for Ukrainians to obtain a visa for an EU country, even to attend EU-sponsored events designed to promote multicultural cooperation. As a result, Ukrainian school groups have had to cancel trips to Bieszczady, and few Ukrainians participate when meetings associated with the Carpathian Euroregion take place outside of Ukraine. Another participant explained that for years he played on a local soccer team that would have tournaments with Ukrainian and Slovak teams, but the Ukrainians can no longer participate unless the games are held in Ukraine. With limits on the flow of people, there has also been a corresponding unidirectional shift in the movement of people involved in cross-border trade. Fewer Ukrainian vendors attend weekly markets in Bieszczady, which before 2004 overflowed with goods from across the border. Instead, Poles travel to Ukraine for items such as candy, alcohol, and gas which are less expensive than in Poland. Such conditions, where transborder flows move more freely in one direction than the other, produce a kind of hierarchy between those with the right to cross borders and those whose movements are restricted. ${ }^{21}$ Furthermore, it has the potential to strengthen oppositional identities between $\mathrm{EU}$ member and nonmember nations.

\section{CULTURAL DIVERSITY AND ETHNIC MINORITIES}

In addition to cross-border cooperation, EU discourse about multiculturalism also highlights the value of cultural diversity within an increasingly cohesive Europe. In Bieszczady, most talk of diversity steers clear of cultural politics related to contemporary issues like sexual preference, instead favoring a narrow interpretation celebrating the cultural distinctiveness of ethnic minorities. Regional cultural programs further concentrate on the cultural heritage of ethnically diverse communities that no longer exist. Instead of promoting a living community, an "idea of multiculturalism" is recreated through the objects and performances that mark past communities - ruins, an outdoor architectural museum, and folk music and dance. In this way, multiculturalism provides the rationale for a constellation of cultural development projects that promote Bieszczady's multiethnic heritage in the absence of contemporary multieth-

20 See K. Szmagalska-Follis, 'Repossession: Notes on Restoration and Redemption in Ukraine's Western Borderland', Cultural Anthropology, Vol. 23, No. 2 (2008), pp. 330, 344, at <http://dx.doi. org/10.1111/j.1548-1360.2008.00011.x>.

${ }^{21}$ For a discussion of the impact of degrees of mobility on social stratification, see Z. Bauman, Globalization. The Human Consequences, New York 1998, pp. 85-102 (European Perspectives). 
nic communities. Memory projects remain highly selective processes. As the history of the region has become increasingly associated with Ukrainian villagers, the historical population of Jews has been for the most part ignored in locally-driven EU-funded projects. Preservation of Jewish heritage sites remains the focus of Jewish international organizations.

As I have noted, Bieszczady was effectively Polonized by the state socialist regime, and the vast majority of the roughly 70,000 Bieszczady residents today consider themselves Polish. ${ }^{22}$ After World War II, small pockets of Ukrainian-identified residents continued to quietly practice their faith and native language in private. As early as the late 1970s, a handful of folk dance groups and youth groups emerged, but it was only after 1989 that more residents became public about their ethnicity, and for example, acknowledged they were Ukrainian to their schoolmates or began talking Ukrainian outside their homes and churches. Komańcza is one of the few places in which there has been some investment in "continuing traditions" among resident ethnic minorities. ${ }^{23}$ A good example of this is the "Two Cerkiews Project", funded by the European Regional Development Fund (ERDF) with the cooperation of the Orthodox Church and local governments in Komańcza and Habura, Slovakia. When the historic wooden cerkiew (church) in Komańcza was destroyed in a fire in 2006, regional representatives allied with representatives from Habura who wanted to build a replica of a historic wooden church that had been sold and moved from their village in 1935. According to the project's website: The "Two Cerkiews Project" is a transborder investment which contributes to improving conditions for economic development based on cultural heritage in the Komanicza and Habura districts... The project involves the participation of all partners in the protection of cultural heritage of the Polish-Slovak border region, while simultaneously raising awareness about cultural identity among youths... [The cerkiews] form the basis for maintaining religious and cultural identity for residents of the region. ${ }^{24}$

The site displays the familiar EU logo of gold stars on a blue background, and acknowledges cofunding of the ERDF under the PL-SK 2007-2013 Partnerstwo dla Wspólnego Rozwoju (Crossborder Cooperation Programme Poland-Slovak Republic 2007-2013). Significantly, however, although $85 \%$ of the funds for the project came from the EU, this is not always acknowledged. Church sources in Komańcza emphasize the private contributions of community members. Similarly, a report on Radio Prague says, The [cerkiew] copy was built thanks to two influential citizens - a successful financier and a former Czechoslovak government minister, with no mention of the EU's participa-

22 This figure is based on the population of the following districts and communities: powiat Bieszczadzki (22,262); powiat Leski (26,643); gmina Zagórz (12,658); gmina Komańcza (5,139) reported by GUS (Główny Urząd Statystyczny - Central Statistics Office), Powierzchnia i ludność w przekroju terytorialnym $w 2006 r$. at <http://www.stat.gov.pl/dane_spol-gosp/ludnosc/powierz_teryt/2006/ pow_lud_teryt_2006.pdf>, 10 February 2010.

23 Dwie Cerkwie - zbliżenie kultur pogranicza Polski i Stowacji, at <http://dwiecerkwie.pl/>, 27 August 2013.

24 Ibid. 
tion, nor of the partnership with Poland.$^{25}$ Recognition of the connection between this regional cultural project and cohesion in Europe is tenuous at best, overshadowed by local, religious, and church loyalties.

While in Komańcza the contemporary multiethnic population gains recognition through projects such as the "Two Cerkiews Project", elsewhere only the idea of such communities is left to be preserved. Cultural projects that seek EU sponsorship thus tend to highlight the historical ethnic diversity of the region. The architectural styles, religious practices, and cultural traditions of prewar residents are not only publicly acknowledged by regional leaders and the Polish majority, but also celebrated in cultural festivals and on historic markers. Moreover, educators and employees of nonprofit organizations actively construct a story about the region that they can teach other residents in order to build in them a sense of pride and connection to place. As one school principal explained, We are reaching for our roots, putting great effort into building in children that identity and attachment to this land, but also to give them an equal chance. She links multicultural heritage to economic opportunity. However, significantly, these efforts are not intended to be at the expense of Polish national identity. On the contrary, this principal is a self-avowed Polish patriot who aspires to instill the same deep national sentiments in her students. In other words, she seeks to appropriate remnants of historical cultural diversity in order to advance contemporary regional, overwhelmingly Polish, interests.

Because local identity is in the process of construction, it is not surprising that certain resistances have manifested among participants toward the regional history and culture most commonly promoted in conjunction with the EU multicultural agenda. One participant, a teacher who descends from a Polish-identified autochthonous family and who has actively engaged in a variety of EU-funded cultural heritage projects, complained that some people are remaking the region into a historically Ukrainian territory and disregarding its ethnic Polish roots:

Poles also lived in this region, darn it, and I don't understand how suddenly a tradition appeared connecting our territory with the tradition of Łemko and Bojko, [ethnic groups that were] Ukrainian, kind of, but their own different ethnicities. Everyone wants to make this into Ukrainian territory. So regional dishes become Ukrainian, and the Polish culture is lost. I've also seen this fashion for preserving so called Eemko cottages, when they are definitely Polish cottages - of the "Valley People" [Dolinianie, Catholics who spoke a dialect more akin to Polish]. I'm telling you, Valley People lived in cottages like that, don't upset me. Just go and look.

I am a tolerant person, but I have noticed that some people at all costs want to identify with some different nation than Poland. Because that way it is easier for them to attract tourists.

This teacher is critical of residents who know little about the complex history of Bieszczady and promote a narrative about Ukrainian villagers in order to make their businesses more attractive to tourists eager for a unique cultural experience. Taken by

25 D. Lazarová, 'News from the Regions', 14 July 2011, Radio Praha, at <http://www.radio.cz/en/section/panorama/news-from-the-regions >, 27 August 2013. 
itself, the quoted passage might seem to suggest that she is invested in rewriting regional history to fit a Polish-centered narrative. In fact, she has a deeper understanding of the historical diversity of Bieszczady than most, and has worked tirelessly to obtain funds from the EU so that her school can provide students with opportunities to learn about the Bieszczady region and about the EU.

In the absence of living populations, invented traditions are enacted by local (and national) interests trying to capitalize on historic diversity and advance regional development schemes. ${ }^{26}$ Ethnological sources from the early $20^{\text {th }}$ century note that before World War I, most residents would have identified themselves as "tutejsi" ("from here"), and allied with their religious faith more readily than with a national or ethnic group. ${ }^{27} \mathrm{As}$ the national idea took hold in the $20^{\text {th }}$ century, village residents started to adopt the labels "Ukrainian" or "Polish", with Orthodox or Greek Catholics more likely to consider themselves (and to be considered) Ukrainian and Roman Catholics more likely to see themselves (and be seen) as Poles. As Buzalka notes, even when multiculturalism is celebrated in contemporary state-sponsored festivals and public displays, these practices serve to fix Ukrainian and Polish identities in ways that inscribe the contrast between them. This "artificial tolerance", controlled by elites and state interests, replaces the "ordinary tolerance" of the past, when Greek Catholics were more likely to accept a variety of Roman Catholic symbols and rites, and mixed marriages contributed to more fluid identifications within families, and even across the life course. ${ }^{28}$ This is not to say that relations in the past were free of conflict (they were not) but rather, that ethnic distinctions are being reified by the very policies and practices designed to promote cohesion among ethnically diverse populations. The point I want to make is that it is easier to treat ethnic boundaries as fixed and unchangeable when one group is no longer present - as a figure of imagination and memory it can be inscribed in whatever way suits contemporary circumstances, with no minority representative to challenge that portrait.

A final example illustrates how local needs are adapted to the priorities of the funding agency, and how "fit" with the value of multiculturalism can compete with another goal of European Social Funds - to equalize chances for vulnerable groups like rural children. Specifically, I examine applications by two schools for the "Szkota Marzeñ" (School of Dreams) program, which targeted increasing educational opportunities for students from rural communities. The main goal of European Social Funds is to fight unemployment, especially for the most vulnerable social groups. They variably encourage opportunities for mobility (within or between EU countries), promote access to education, job retraining, and employment opportunities, and emphasize marketable skills, innovation, and adaptability. ${ }^{29}$ Recognizing the shortage of jobs in

26 E. Hobsbawm, 'Introduction: Inventing Traditions' in E. Hobsbawm, T. Ranger (eds.), The Invention of Tradition, Cambridge 1992 [1983], pp. 1-14.

27 J. Falkowski, B. Pasznycki, Na pograniczu...

28 J. Buzalka, Nation and Religion..., pp. 131-157.

29 M. Pudlak, 'Europejski Fundusz Społeczny' in W. Bokajło, K. Dziubka (eds.), Unia Europejska..., pp. 447-449. 
rural areas, the Szkoła Marzeń program identified four priorities: to ensure equality of educational opportunities; to help students choose educational and career paths; to shape active attitudes towards social change; and to mobilize local communities around common activities for education and upbringing. Schools were encouraged to partner with local government, businesses, and other cultural organizations. ${ }^{30} \mathrm{In}$ practice, the program funded extracurricular activities, many of which highlighted regional history and culture.

I spoke with officials at a college-preparatory lyceum that received funding and a village middle school that did not. The differences between the schools reflect structural distinctions that reproduced occupational class divisions even during state socialism. Lycea emphasize academic subjects and admit the most academically inclined students; children of elite families are more likely to attend. Village children are more likely to select technical or trade schools that emphasize occupational skills. Starting in the 1990s, in response to the transformation of work opportunities within a neoliberal economy, national education reforms encouraged more students to complete general academic tracks at the secondary school level, which would prepare them for higher education. The middle school serves younger students who have not yet entered college preparatory or vocational tracks, and who come from more rural, less affluent families - the very population Szkoła Marzeń was designed to assist. Although the lyceum meets the program requirement that at least $35 \%$ of the students come from rural counties, it is located in a town and tends to admit the children of teachers, business owners, doctors, and the like. Nevertheless, it was the lyceum that received funding.

The lyceum's proposal emphasized extracurricular activities designed to help students develop skills and gain knowledge that would be useful in Bieszczady's growing tourism industry. Opportunities included a variety of art clubs, outings into the mountains, and fieldtrips to regional historical sites. All of these activities emphasized regional cultural heritage and natural history; for example, there were competitions for the best photographs related to the local flora and fauna, and journalism students wrote articles about the history of Bieszczady for a local newspaper. Students were also offered career counseling to help them identify the profession best suited to their abilities and interests. The middle school included some elements intended to strengthen local identity, but tried to meet the program's first priority, equalizing chances, by providing opportunities for students to learn about the places that are most significant for national culture and history. To that end, the proposal included fieldtrips to Krakow, Warsaw, and Gdansk. The school principal explained the importance of rural children having some familiarity with city life, including things as basic as public transportation, so they will be comfortable venturing out of their village.

The kinds of ethnic memory work the two schools proposed differ in another way, as well. The director of the middle school expressed a commitment to helping children connect with the diverse origins of their own families - many of whom came from Polish families resettled from postwar Ukraine and Belarus (Republics of the USSR),

30 This description is based on application instructions and applications submitted by two schools. 
while others moved from central Poland in search of employment in state industries and state farms. Significantly, despite their different territorial origins, these families identified as ethnically Polish; the diversity they represent is still encompassed by the Polish nation. Furthermore, the director expressed other explicitly pro-national goals. She wanted to reinforce students' connection to the Polish cultural core, via field trips to major Polish cities. The lyceum program, by contrast, celebrates the idea of local multiculturalism, via promotion of the folk arts and heritage of former communities, without the expectation that students have any direct family ties to them. Indeed, because the region was virtually depopulated after World War II, most students' families came from other regions of Poland. ${ }^{31}$

I suggest that the middle school's proposal was rejected, in part, because it was founded in a memory project at odds with the EU vision of multiculturalism, reinscribing instead a model of nations divided hierarchically into center and periphery, where citizens of peripheral regions must look to the economic and cultural core for resources and opportunities. The lyceum, by contrast, sought to package ethnic heritage as a key distinguishing feature of the Bieszczady region; further, it set out to teach children to use this regional distinctiveness as a tool for stimulating tourism, and in that way create employment opportunities in Bieszczady. The irony, of course, is that the middle school principal responded to the existing diversity in her community, while the lyceum advanced an idea of diversity based on ethnic categories that are largely absent.

\section{TRANSNATIONAL REGIONAL COMMUNITY}

Although "transnational regional community" sounds like an oxymoron, it is an apt characterization of the Bieszczady region for a number of reasons. As Anthony Giddens (1991) has noted, reflexivity engendered by comparisons with an ever-expanding range of different groups often leads to the elaboration of the local. There is a similar notion in globalization theory that the global and local are mutually constitutive. For residents of Bieszczady, membership in the transnational institution of the European Union provides a context in which regional identities become more salient. First, the EU becomes a basis for comparison - people strengthen their sense of who they are via contrasts with outside groups with whom they have more extensive contact. Subsequently, within this international context, they find more reason to define themselves to outsiders; seeking to make their region appealing to tourists and investors, they search for what makes it distinctive. EU values of multiculturalism and diversity

31 It is also important to note that both schools have remarkably competent and committed staff who have pursued EU-sponsored funding for a range of projects, and both have obtained funding for other projects. The lyceum has received a number of grants for school upgrades, and the middle school has received funds to establish a "green classroom" that features the unique geography of the mountains. As is typical of the social actors I spoke with, the principal of the latter school was not discouraged by their failure with the Szkoła Marzeń program. We feel a little satisfaction that we tried and more than anything some knowledge has been gained, she said, so we have to be optimists. 
encourage residents to celebrate the cultural and historical roots of Bieszczady that lead not to the core of Polish society so much as to connections that extend beyond the political borders of the country. Environmental projects focus on the mountain ecosystem of the Carpathian Euroregion which encompasses parts of Poland, Ukraine, Slovakia, Hungary, and Romania. Cultural projects emphasize autochthonous ethnic groups who historically populated mountain villages in Poland, Ukraine, and Slovakia. ${ }^{32}$ Yet another way in which regional communities extend beyond this particular locale is via memories of lost homelands, left behind when nation-states sought to engineer ethnic homogeneity during and after World War II.

With regard to the question about the continued strength of national allegiances in the face of multicultural values encouraged by the EU, perhaps, as is suggested by the category "transnational regional community", what is happening on the ground is really more a matter of "both/and" than "either/or". Participants are motivated by their deep sense of attachment to Bieszczady, often in conjunction with strong allegiances to the Polish nation. I have cited instances where their commitment to multiculturalism has been shallow, engaged in the service of regional (and national) interests. But participants also express real interest in the multicultural history of their region, and a genuine desire to forge connections across religious, political, and ethnic boundaries. Some embrace multiculturalism as a characteristic of Poland, harking back to earlier multiethnic kingdoms and the interwar state. Increased attention from Europeans who live outside Poland's borders is viewed as a legitimation of the specialness of their place. Further, projects promoting multiculturalism expose the country's current ethnic homogeneity as neither inevitable nor necessarily ideal; rather, it is an artifact of specific atrocities of the $20^{\text {th }}$ century. Further, the reemergence of ethnic minorities from the privacy of their own homes occurred in response to the rhetoric of openness and freedom that defined the break from state socialism over a decade before EU integration. While this suggests that there is a growing sense that ethnic and religious diversity belongs within Poland, ethnicity still tends to be treated as a "thing" that groups possess, either as a right of birth or acquired through residence and cultural practice. Furthermore, recognizing the heritage of ethnic and religious minorities easily slips into appropriation of those various groups' history and culture as part of Polish history and culture. ${ }^{33}$ These tensions, played out in residents' discourse and practice, signal a more complex picture of region, nation and $\mathrm{EU}$ integration within a transnational regional community.

The social actors interviewed for this study have been instrumental in shaping and disseminating information about Bieszczady's past and helping to preserve the distinctive character of its towns and villages against the backdrop of membership in the European Union and increased tourism. The transnational context has served to strengthen regional ties, and international funding for cross-border projects has contributed to this

32 J. Falkowski, B. Pasznycki, Na pograniczu..., captures much of the history, customs, and folklore of these groups in their ethnological study.

33 I. Irwin-Zarecka, Neutralizing Memory. The Jew in Contemporary Poland, New Brunswick 1989; J.D. Zimmerman, Poles, Jews, and the Politics of Nationality. The Bund and the Polish Socialist Party in Late Tsarist Russia, 1892-1914, Madison (Wis) 2004. 
process. ${ }^{34}$ In other words, the transnational regional community that has emerged exhibits both the convergences and the disjunctures between EU values of multiculturalism and local goals of regional cultural and economic prosperity.

\section{BIBLIOGRAPHY}

Appadurai A., 'Global Ethnoscapes: Notes and Queries for a Transnational Anthropology' in J.X. Inda, R. Rosaldo (eds.), The Anthropology of Globalization. A Reader, Malden (Mass.) 2008 (Blackwell Readers in Anthropology, 1).

Bauman Z., Globalization. The Human Consequences, New York 1998 (European Perspectives).

Bokajto W., Dziubka K. (eds.), Unia Europejska. Leksykon integracji, Wrocław 2003.

Buzalka J., Nation and Religion. The Politics of Commemoration in South-East Poland, Berlin 2007 (Halle Studies in the Anthropology of Eurasia, 14).

Caldwell M., 'Domesticating the French Fry: McDonald's and Consumerism in Moscow', Journal of Consumer Culture, Vol. 4, No. 1 (2004), at <http://dx.doi.org/10.1177/ $1469540504040902>$.

Chessa C., 'State Subsidies, International Diffusion, and Transnational Civil Society: The Case of Frankfurt-Oder and Słubice', East European Politics and Societies, Vol. 18, No. 1 (2004), at $<$ http://dx.doi.org/10.1177/0888325403260962>.

Chua A., World on Fire. How Exporting Free Market Democracy Breeds Ethnic Hatred and Global Instability, New York 2004.

Dwie Cerkwie - zblizenie kultur pogranicza Polski i Stowacji, at <http://dwiecerkwie.pl/>.

European Regional Development Fund (ERDF) (2007-2012), Summaries of EU Legislation, at <http://europa.eu/legislation_summaries/agriculture/general_framework/g24234_en.htm>.

Falkowski J., Pasznycki B., Na pograniczu temkowsko-bojkowskim. Zarys etnograficzny, Lwów 1935.

Fastnacht A., Dzieje Leska do 1771 roku, Rzeszów 1988.

Foster R., Coca-globalization. Following Soft Drinks from New York to New Guinea, New York 2008.

Hobsbawm E., 'Introduction: Inventing Traditions' in E. Hobsbawm, T. Ranger (eds.), The Invention of Tradition, Cambridge 1992 [1983].

Irwin-Zarecka I., Frames of Remembrance. The Dynamics of Collective Memory, New Brunswick 1994.

Irwin-Zarecka I., Neutralizing Memory. The Jew in Contemporary Poland, New Brunswick 1989.

Kiwan N., Meinhof U.H., 'Perspectives on Cultural Diversity: A Discourse-Analytical Approach' in U.H. Meinhof, A. Triandafyllidou (eds.), Transcultural Europe. Cultural Policy in a Changing Europe, New York 2006.

34 Chessa discusses similar processes along the German-Polish border. See C. Chessa, 'State Subsidies, International Diffusion, and Transnational Civil Society: The Case of Frankfurt-Oder and Słubice', East European Politics and Societies, Vol. 18, No. 1 (2004), pp. 70-109, at <http://dx.doi. org/10.1177/0888325403260962>. 
Kubik J., The Power of Symbols against the Symbols of Power. The Rise of Solidarity and the Fall of State Socialism in Poland, University Park 1994.

Lazarová D., 'News from the Regions', 14 July 2011, Radio Praha, at < http://www.radio.cz/en/ section/panorama/news-from-the-regions $>$.

Lehman R., 'Social(ist) Engineering: Taming the Devils of the Polish Bieszczady', Communist and Post-Communist Studies, Vol. 42, No. 3 (2009), at <http://dx.doi.org/10.1016/j.postcomstud.2009.07.004>.

Meinhof U.H., Triandafyllidou A., 'Transcultural Europe: An Introduction to Cultural Policy in a Changing Europe' in eaedem (eds.), Transcultural Europe. Cultural Policy in a Changing Europe, New York 2006.

Pudlak M., 'Europejski Fundusz Społeczny' in W. Bokajło, K. Dziubka (eds.), Unia Europejska. Leksykon integracji, Wrocław 2003.

Szmagalska-Follis K., 'Repossession: Notes on Restoration and Redemption in Ukraine's Western Borderland', Cultural Anthropology, Vol. 23, No. 2 (2008), at <http://dx.doi. org/10.1111/j.1548-1360.2008.00011.x>.

Thum G., Uprooted. How Breslau Became Wroctaw during the Century of Expulsions, Princeton 2011.

Tsing A., 'The Global Situation', Cultural Anthropology, Vol. 15, No. 3 (2000), at <http:// dx.doi.org/10.1525/can.2000.15.3.327>.

Wallerstein I., The Capitalist World-Economy. Essays, Vol. 2, Cambridge 1979 (Studies in Modern Capitalism).

Watson J. (ed.), Golden Arches East. McDonald's in East Asia, Stanford 1997.

Welcome to EQEAL, European Commision, at <http://ec.europa.eu/employment_social/ equal_consolidated/index.html>.

Zimmerman J.D., Poles, Jews, and the Politics of Nationality. The Bund and the Polish Socialist Party in Late Tsarist Russia, 1892-1914, Madison (Wis) 2004.

Marysia GALBRAITH is an associate professor at The University of Alabama with a joint appointment in the Department of Anthropology and the interdisciplinary New College Program. Her areas of specialization include national and ethnic identity, globalization, postcommunist Poland, and European integration. Her articles have been published in the Anthropological Journal of European Cultures, the Journal of the Society for the Anthropology of Europe, Ethos, Anthropological Quarterly, and Ethnologia Europaea; her forthcoming book is titled Being and Becoming European in Poland: Self-Identity and European Integration. 